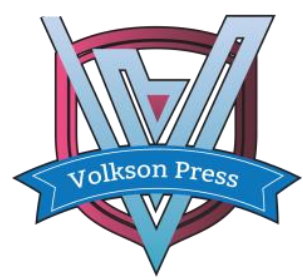

Contents List available at VOLKSON PRESS

Economics \& Management Innovations(EMI)

DOI : http://doi.org/10.26480/icemi.01.2017.116.118

\title{
Chinese Government's Inspiration from Foreign Governments' Experience in Real Estate Market Management
}

\author{
Yang Yuchen ${ }^{1, *}$, Meng Qingjun ${ }^{2}$ \\ ${ }^{1}$ No.687 Zhujiang Road, Xuanwu District, Nanjing, China \\ 2 Room 411, Boxue Building, No.8 West Focheng Road, Jiangning District, Nanjing, China \\ *136870750@qq.com \\ This is an open access article distributed under the Creative Commons Attribution License, which permits unrestricted use, distribution, and reproduction in any \\ medium, provided the original work is properly cited.
}

\section{ARTICLE DETAILS}

\section{Article History:}

Received 02 october 2017 Accepted 06 october 2017 Available online 11 october 2017

\section{Keywords:}

real estate market; government; stakeholders;

\section{ABSTRACT}

Real estate industry, as an obviously important force in the economic development of various countries, is closely concerned by the government with strengthened management measures. The problems of harmony about the rights and obligations between stakeholders lead to many problems in this market, such as the investment risk, unreasonable market structure, malicious speculation and so on. Chinese government can learn the effective management measures from foreign governments in the real estate market, to hold market equity, maintain fair market transactions, supervise market order, respect reasonable transactions, protect the residence rights of lowincome groups and promote the orderly development of the market.

\section{Introduction}

Real estate market has an important influence on the national economic development. The real estate markets of many cities in the world are featured by fast appreciation main value and strong maintenance of value, which tend to be pursued by investors. With China's economic development, some economically-powerful Chinese real estate investors start to enter into international real estate market, such as London, New York and other cities to look for opportunity of gaining profit. For example, in 2014 London occupied $14.1 \%$ of the investment volume in global real estate market, ranking the first. In 2015, influential entrepreneur Wang Jianlin of Chinese real estate industry spent 80 million pounds to buy a luxury villa in London, UK and paid about 9.5 million pounds of stamp duty.

The impact of multiple stakeholders on the real estate market has changed, and the real estate market in each city is full of risk and difficult to master. In general, the ratio of housing price to income of international metropolis in Europe and the United States maintains at about 4 to 6, but the ratio is nearly 15 in Beijing and Shanghai. The house property has a commodity attribute, however, more importantly, it is to meet the housing needs. Investment-induced high housing price has led to huge housepurchase pressure on ordinary residents. Therefore, in order to manage the market order through reasonable managements and balance the interests of the multiple stakeholders to promote the harmonious and stable life of the city, the government should make effective managements of the real estate market.

\section{Related Researches}

A number of scholars have discussed about the measures that the government should take in the development of the market, the role it plays and the responsibilities it assumes, and made recommendations combined with foreign experience. For example, Xu Xianchun et al. (2015) confirmed that the real estate industry played an important role in China's economic growth through statistical analysis, and considered that it was necessary that the government took measures to stabilize the real estate market. Wang Chongyu and Wang Feng (2016) found that the rapid inflow of money and high leverage ratio played an important role in the increase in property price of the time in China, especially in metropolis. Xiao Xinru (2014) took Shanghai as an example, and analyzed multiple factors influencing the living patterns of the migrant young people with high academic degree by using the polyatomic logistic model. She confirmed that it included the impact of individual differences, urban integration, as well as the market and macroscopic policies. Yang Chengzhang (2016) considered that the supply and demand and trading system design of Chinese real estate market created conditions for the speculators, thereby inducing the property bubble and the risk of over speculation. Zhang Keyun and Yang Mengyu (2015) focused on the new field of urban "space mismatch". They used American experience for reference and put forward warning recommendations on the Chinese government urban housing governance in the household registration differences, the gap between rich and poor and housing market policy and other aspects.

Of course, the local government should adopt different management countermeasures for different cities according to their own real conditions. The real estate industry is not only an important driving force of urban economic growth, but also has far-reaching influence on the industrial structure, development potential, social order, living standards and other aspects. It can be a way for assets holder to realize appreciation during rational development, and there is low risk of price slump. At the same time, a healthy market environment leads to steady fiscal revenue, and also shows a good image of the city. But if the market order is disturbed by speculation, thus resulting in skyrocketing price, it not only will reduce the purchasing power of low-income people, but also induce short-sighted behaviors of financing and intermediary. In this way, it increases government management cost, and also damages the city image. What's worse it may likely increase house property value fluctuation and financing reimbursement risks due to unstable market environment. Therefore, the city manager is obliged to take appropriate measures to attract investment and make rational development of the real estate market on the one hand, and meet the housing demand of ordinary residents in the face of very influential real estate market.

\section{Experience of Relevant Countries on the Real Estate Market Management}

\subsection{Distinctive Laws of the Real Estate}

The government has no right to interfere with the red-hot real estate market and high housing price, but can help low - income groups enhance the ability to purchase a house. Former London Mayor Boris Johnson launched a "shared property right" program, proposing that house buyers can choose to purchase $25 \%-75 \%$ of the housing property right, and pay for the rest by rent. The current mayor of London also said that the policy 
should be made to control the inflow of foreign capital into London strictly, making $50 \%$ of the new housing affordable for the ordinary people. The New York government has adjusted the original voluntary inclusive compartment into mandatory compartment regulations and building codes to increase the supply amount of affordable houses in high-density areas. In 2016, Shanghai promulgated control policies for thrice, covering the purchase limitation, loan limitation, land management and people management. In particular, the house buyers who get the loan qualification through "fake divorce" are subject to strict examination.

\subsection{Tax Revenue with Detailed Rules and Regulations for} Implementation

In Britain, America and other countries, real estate tax is the main way for local governments to raise fiscal revenue. The local government tends to adjust the housing holding costs through the stamp duty. From April 1, 2016, Britain began to collect additional stamp duty on real estate. Person who buys a second house or earns rental income needs to pay an additional $3 \%$ of stamp duty. In consideration of the economic capacity of ordinary residents in New York, they only need to pay a small amount of real estate transaction tax and real estate tax for purchase of house property, and only need to pay $1 \%$ of real estate tax every year. The government can increase the holding and transfer costs of real estate holders through the implementation of up to $55 \%$ of inheritance tax. Hong Kong introduced "ad valorem stamp duty" in order to curb real estate speculation, and increased the tax rate to $15 \%$ in 2016. In 2016, State Administration of Taxation Shanghai stipulated the implementation of $11 \%$ of VAT rate for real estate development enterprises and $1.5 \%$ of VAT rate for individual housing rental.

\subsection{Strict Financial Measures of Real Estate}

The real estate financial policy involves deposit interest, loan interest rate, mortgage and other aspects. The government uses this means to regulate the buying and selling pressure of the entire real estate market. For example, the 2016 British financial budget proposed a three-year "Help to Buy", to help residents buy a house through interest-free loans or mortgage guarantees. For example, people who bought the first house of less than 600,000 can enjoy $40 \%$ of interest-free loans within five years. The New York government is actively seeking for investment leverage in the public sector, by issuing rewards to property developers, establishing foundations and so on. The Hong Kong Monetary Authority has adjusted the loan-to-value ratio timely to control the state of real estate market, and lowered the loan-to-value ratio of building in 2010. Shanghai has strict regulations on the down payment ratio, credit ceilings and threshold of housing public accumulation funds of house buyers.

\subsection{Reasonable Housing Welfare Measures}

Britain is carrying out the commercial residential building and low - rent housing mixed system currently, whose low - rent housing proportion in London has exceeded 50\%. Residents who have already lived in low - rent housing can buy the house they are living in now at preferential price according to the living period of time. In May 2014, the New York Mayor launched a new "ten-year housing plan" to build 80,000 affordable houses. The public housing system is welfare housing financed by the Hong Kong Government, to solve the housing problem of middle and low income earners and enhance the utilization rate of limited land in Hong Kong. In 1997 , the people who were living in welfare housing accounted for $50.97 \%$ of the total population of Hong Kong. In February 2016, Shanghai explicitly stipulated that the proportion of socialized leasing housing among the newly-sold commercial residence land should be not less than $15 \%$. In October, the government required to increase the proportion of security housing (including talent apartments) in the land for commercial housing further.

\subsection{Housing Agency under Supervision}

The majority of British house prosperity transactions are completed through house property agents. For example, the house transactions completed through house property agents accounted for more than $90 \%$ of the total amount in England. The British government supervises the housing agency from its establishment, qualifications and other aspects through the OFT, and even regulated the market order with hefty penalties when necessary. Governor Paterson made New York the first state in the US to legislate for criminal punishment on the fraud and breach of contract during real estate transactions. Hong Kong issued many guidance documents on the sales and initial low-price sale amount of property developers, committed to reducing property developers' control of sales and restraining the housing price. In October 2016, Shanghai announced 75 illegal real estate companies and intermediaries for two consecutive times, exposing their false propaganda and false advertisement.

\subsection{Serious Land Planning and Management}

The cities with real estate market red-hot are usually faced with the contradiction between high - density population and limited land resources. The British government improved the efficiency of land use and residential density to achieve sustainable housing supply according to the research of Katie Barker. In 2005, the average density of newly-built residential buildings in London increased from 56 sets to 102 sets per hectare. New York released land potential through small plot infil development and redevelopment of low-efficient plot, to increase the opportunity for the construction of affordable housing. Hong Kong has relatively sound land legislation systems, according to which the government manages land supply and makes plan for the city. Shanghai enacted six policies named "Shanghai Six" to strengthen the supervision of the capital source for the commercial housing land trade, emphasizing that bank loan, trust funds, capital market financing, etc. shall not be used as guarantee money, deposit or follow-up land transfer payment.

\section{Countermeasures on Urban Real Estate Market Management} from Chinese Government

\subsection{Focusing on Supply and Demand Balance, and Abiding by the National Guidance Strategy}

According to the 2016 Market Survey Report of Real Estate in Mainland China, Shanghai is still the most promising city for investment in China and property developers are also creating new "land king" constantly in the land auction. China's urbanization level is about $60 \%$, which is far less than the $80 \%-90 \%$ of developed countries. So the special circumstances of China determines that there will be increasing demand for urban housing in a certain period of time in the future. At the critical stage of "supply-side structural reform", the local government needs to play a role of control in land planning. Because of the private land ownership, the British local authorities are unaware of what kind of land each landowner wants to develop. But in China, the government has huge administrative power to determine the land development methods, time and so on. Therefore, the government needs to simplify the land supply process, and conduct demolition according to law, to increase the land supply amount reasonably, and plan its usage well and control the transaction price, thus joining in the development of urban real estate from the supply side, to improve the efficiency of the use of limited land, thus meeting the demand for market development.

\subsection{Improving the Market Order, and Fighting against Malicious speculation}

The real estate market is not a complete market, which should be regulated by the government in time Chinese people have a traditional idea of "living and working in peace and contentment", for whom a large amount of real estate not only helps them preserve and increase value, but also provides a way for them to "show off their wealth". Because of the special purchasing psychology, Chinese investors prefer to invest in real estate. In order to regulate the market order, the government should refine the laws and regulations, set specialized agencies, and make indepth and continuous supervision on the intermediaries, developers, house buyers, etc. In particular, the "real estate speculation", "selling house number" and other malicious speculation, and behaviors disturbing the fair trade should be punished and suppressed severely and resolutely. The government should enhance the transparency of the real estate market information, thus reducing the back room operations to product the rigid demand of house purchase, and improving the spread speed of relevant transaction information and the management level and service quality of the government.

\subsection{Improving the Housing Guarantee System, and Implementing the Hierarchical Housing System}

No matter how much the property price rises, the government has no administrative power to control the normal trading of commercial residential building. For the low-income groups, the Government needs to increase the supply of security housing, and improve the application, examination and approval procedure of security housing. More importantly, under the entire welfare housing system, the government should grade the payment capacity, to provide equal housing benefits. In the meanwhile, it should improve the housing rental market, and manage the contract of the lessor, lessee and intermediary to protect the interests of all parties, in this way, allocation efficiency of limited administrative resources will be increased, and it can also reflect the policy limitations of the government, so as to encourage low-income earners to improve their 
economic strength. What's more, the talent is an important potential for the urban development. For young people who have just joined in the big cities, comprehensive housing policies and benefits are the key factors that attract them to stay.

\subsection{Using Indirect Means to Enhance Market Regulation Effects}

The administrative management means are effective and powerful, which may also become a new obstacle to the development of the real estate market. The government makes adjustment indirectly by using taxation, finance, etc., which emphasizes the essence of the pursuit of benefits in the market with diversified investment sources. The government should also be clear about its position in the market, to make its management means more in line with the laws of the market economy, to cooperate with the market participators better. Therefore, the government can collect the real estate tax by defining the per capita area, or manage the real estate market through making strict regulation on financial instruments. It can also affect the investors through increasing the house prosperity transaction and holding costs of investors, and taking advantage of the environment changes, thus achieving the control of speculation, the guarantee of fairness and the reduction of financial risks. This also makes the management results of the government more rational and sustainable.

\section{Conclusions}

The continuous increase of house price in the real estate market of China in recent two years has nearly approached its limit. It is necessary for the government to take measures to control the real estate, because it is not only crucial to regional economic development, but also related to people's livelihood and social stability. Therefore, President Xi Jinping put forward that "the house is built to live, not to be speculated". The instruction is to make the real estate market go back to the normal state with the efforts of local governments. So, managements should focus on maintaining market equity, supervising market order, respecting reasonable transactions and promoting market development, attaching importance to the establishment of a sound housing guarantee and subsiding system to protect the housing right of low-income groups.

\section{References}

[1] Information on http://www.gov.cn/zhengce/2016$\underline{12 / 16 / \text { content 5149066.htm }}$

[2] Information on http://news.xinhuanet.com/overseas/2015$\underline{12 / 20 / c 128548828 . h t m}$

[3] Xu Xianchun, Jia Hai, Li Jiao, et al, in: A Study on the Effect of Rea Estate Economy on China 's National Economic Growth, edited by Social Sciences in China, China(2015)

[4] Wang Chongyu, Wang Feng, in: Analysis on the Situation of Real Estate Market in China, edited by China Real Estate, China(2016)

[5] Xiao Xinru, in:The Living Pattern of Young Floating Population and Its Influencing Factors in the Big Cities - Taking Shanghai as an Example, edited by Population and Society, China(2014)

[6] Zhang Keyun, Yang Mengyu, in: Research on Urban Spatial Mismatch, edited by Economic Perspectives, China(2015)

[7] Wang Zenghuai, Zhu Aiguo, in: Experience and Enlightenment of Real Estate Regulation in Hong Kong, edited by Financial Aspect, China (2011)

[8] Song Guoming, in: British real estate management, edited by Land and Resources Information, China(2011)

[9] Yan Li, in: Major Events and Influences of Shanghai Real Estate Market in 2016, edited by Shanghai Real Estate, China(2017)

[10] Alan W. Evans: Economy, Real Estate and Land Supply (China Renmin University Press, China 2013) on 